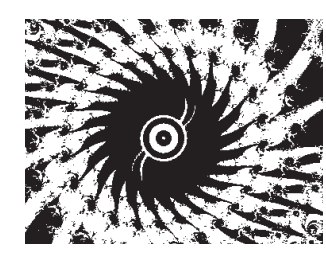

doi:10.5559/di.21.1.09

\title{
ZA MENE, LJUBAV JE...: ANALIZA STUDENTSKIH STAVOVA I DOŽIVLJAJA ROMANTIČNE LJUBAVI
}

Andreja BARTOLAC

Zdravstveno veleučilište, Zagreb

UDK: 316.644-057.875(497.5):177.6

Izvorni znanstveni rad

Primljeno: 6. 8. 2010.

Ljubav je zacijelo jedan od najprivlačnijih vidova emocionalnoga života i ljudskoga ponašanja koji se u nas rijetko istražuje, iako u svjetskim okvirima interes raste (npr. Medora i sur., 2002.; Masuda, 2003.; Watts i Stenner, 2005.; Hendrick i Hendrick, 2005.; Neto, 2007.). Stoga je provedeno istraživanje da bismo saznali kako liubav doživljavaju studenti različite životne dobi, koliko su njihovi stavovi prema ljubavi romantični i jesu li neki sociodemografski podaci povezani sa stavovima prema predmetu mjerenja. U istraživanju su sudjelovala 503 studenta. Ispunili su Knoxov Upitnik stavova prema liubavi te u jednoj rečenici iskazali svoj doživljaj ljubavi. U radu je prikazana kvantitativna i kvalitativna analiza podataka, koji upućuju na umjerenu romantičnost u iskazivanju stava sudionika prema ljubavi. Analizom ispitanih demografskih osobina sudionika pokazalo se da su značajno romantičniji oni sudionici koji su odrasli na selu te oni koji se izjašnjavaju kao izrazito religiozni. Doživliaj ljubavi sudionici iskazuju kroz kategorije: emocije, motivacija, socijalni odnosi i ponašanje. Iz izjava sudionika može se zaključiti da sudionici ljubav doživljavaju kao kompleksnu emociju, motiviranu tjelesnim i duhovnim potrebama, koja u partnerskom smislu započinje zaljubljenošću, a zatim se razvija u odnos obiliežen jednostranim ili uzajamnim ponašanjima davanja i primanja.

Ključne riječi: romantična ljubav, stav, doživljaj

Andreja Bartolac, Zdravstveno veleučilište, Mlinarska cesta 38, 10000 Zagreb, Hrvatska. E-mail: andreja.bartolac@zvu.hr 
Oni se sretnu, zaljube, odluče se vjenčati (ili zajedno živjeti) i nadaju se sretnom životu zauvijek. Tako najpoznatiji kanadski par istraživača, koji se desetljećima bavi rodnim i kulturološkim razlikama u doživljavanju ljubavi, Karen i Kenneth Dion (1993.a), opisuju dobro poznatu nepisanu normu razvoja romantičnog odnosa odraslih osoba. Ovaj idealizirani obrazac razvoja ljubavne veze dobro nam je poznat. Odrastajući s bajkama (holivudskim filmovima), koje imaju imperativ sretnoga završetka, i mi smo odgajani na sličan način; vjerujući da je ljubav sudbonosna emocija koja je izvan naše kontrole, koja rješava sve probleme i koja je najvažniji razlog za ulazak u vezu ili brak (Fowler, 2007.).

No što je zapravo ljubav? Gotovo svatko ima osobnu definiciju nastalu utjecajem socijalizacije i životnog iskustva. Ipak, čim ovu kompleksnu emociju pokušamo sagledati iz biološkog, evolucijskog, povijesnog, kulturološkog, literarnog, filozofskog, teološkog i mnogih drugih kutova, odgovor na to pitanje nije više jednostavan. Subjektivni opisi romantične ljubavi, koji se provlače književnim opusima, ljubavnim napjevima i filmskim scenarijima, teško su znanstveno dohvatljivi. Pokazalo se da je ljubav teže definirati nego što se mislilo. Je li ljubav čežnja ili ushit, ili možda bliskost, strast, odanost, privrženost, nemir, nesebičnost? Ili samo igra hormona i neurotransmitera, mamac za reprodukciju?

Opisi romantične ljubavi u laika obiluju kulturom i socijalizacijom uvjetovanom uobličavanju ljubavi, koje Milivojević (2009.) naziva predstavama o ljubavi. Neke od uobičajenih za naše društvo koje navodi jesu: ljubav je smisao života, prava je ljubav stalna sreća, ljubav je strast, samo jednom se ljubi, prava ljubav traje do kraja života, prava je ljubav bezuvjetna i potpuno predavanje drugome, ona podrazumijeva potpuno razumijevanje, iskrenost i ravnopravnost. Nasuprot tome, razočaranje u ljubavno iskustvo (vlastito ili tuđe) može oblikovati i drugačiji doživljaj ljubavi, primjerice: ljubav je bol, ljubav ne postoji, što je veća ljubav, veća je i ljubomora. Ove narodne, kulturološki uobličene definicije ljubavi, kako ističe autor, ograničene su samo na zapadno, individualističko društvo. Kao primjer za navedeno može poslužiti i Q-metodološka studija Wattsa i Stennera (2005.), koji su izdvojili osam subjektivnih, holističkih iskustava (faktora) partnerske ljubavi britanskih sudionika, a koji će biti prikazani u sklopu kvalitativne obradbe podataka.

Utvrđivanje razlike u doživljavanju ljubavi između kolektivistički i individualistički orijentiranih društava osobito je zanimljivo istraživačima (npr. Simmons i sur., 1986.; Simmons i sur., 1988.; Dion i Dion, 1993.b). Smatra se da je u društvu koje njeguje individualizam romantična ljubav presudan temelj za 
DRUŠ. ISTRAŽ. ZAGREB GOD. 21 (2012),

BR. 1 (115),

STR. 159-180

BARTOLAC, A.:

ZA MENE, LJUBAV JE... brak (Dion i Dion, 1993.a, b). Nasuprot tome, za osobe iz azijske etnokulturološke tradicije pogled na ljubav razvija se postupnije, a partner se doživljava kao brižan pratilac kroz život, prijatelj. No, iako se čini da u kolektivističkim društvima romantična ljubav ima manje značenje, Levinger (1994.) smatra da je ona gotovo univerzalna u ljudskoj vrsti, a kulturalna pravila samo mijenjaju način na koji se ona doživljava, izražava i pamti.

Čudina-Obradović i Obradović (2006.) navode kako se prvi pokušaji znanstvenoga definiranja i operacionalizacije ljubavi javljaju sedamdesetih godina XX. stoljeća, kada Rubin opisuje ljubav kao stav prema drugoj osobi zbog kojeg pojedinac osjeća, razmišlja i ponaša se na specifičan način. To ponašanje može uključivati darivanje, zajedničke aktivnosti, otvaranje prema partneru i intimno povjeravanje (Swenson, 1970., prema Čudina-Obradović i Obradović, 2006.). Knox i Sporakowski $(1968 ., 639)$ citiraju preko pola stoljeća staru, ali još uvijek aktualnu, definiciju: Ljubav je taj intenzivni osjećaj koji dijele dvoje ljudi koji uključuje tjelesnu, emocionalnu i intelektualnu identifikaciju; ... osjećaj koji donosi zadovoljstvo kroz stvaranje osobnog $i$ socijalnog identiteta onih koji su uključeni. Reis i Aron (2008.) objašnjavaju ljubav kao želju za započinjanjem, održavanjem ili proširenjem bliske, povezujuće veze s drugom osobom, dok se Marazziti (2005.) referira na biološke procese $u$ pozadini tog stanja, smatrajući da je ljubav integrirani neurobihevioralni proces kojemu cilj nije samo promocija reprodukcije nego osjećaja sigurnosti, neposrednosti, radosti te smanjenje stresa i anksioznosti.

U težnji da se ljubav sagleda sa svih aspekata, uočava se da postoje različite vrste i dimenzije ljubavi, sastavnice i odrednice, oblici doživljavanja i ponašanja (Aronson i sur., 2005.; Čudina-Obradović i Obradović, 2006.). Najěešća podjela je ona koju spominju Hatfield i Walster (prema Reis i Aron, 2008.) - na strastvenu ljubav, koja podrazumijeva stanje intenzivne čežnje za zajedništvom s drugim, te prijateljsku ljubav, koja se odnosi na naklonost što je osjećamo prema onome s kime smo duboko povezani. Prema Sternbergovoj triangularnoj teoriji, romantična ljubav ne postoji bez strasti i intimnosti. Strastvena komponenta ljubavi opisuje se kao pobuđenost koja dovodi do zanesenosti, tjelesne privlačnosti i seksualnoga ponašanja (Eysenck, 2008.), a povezuje se s uzbuđenjem i novitetom (Reis i Aron, 2008.). Zbog uzbuđenja, teško se koncentrirati na druge aktivnosti, osjeća se intenzivna želja za blizinom i kontaktom, a percepcija voljene osobe je idealizirana. Intimnost se odnosi na osjećaje bliskosti i povezanosti. Štulhofer promatra ljubav i intimnost kao odvojene konstrukte; dok je ljubav uvjerenje kako je (barem u tom trenut- 
DRUŠ. ISTRAŽ. ZAGREB GOD. 21 (2012), BR. 1 (115)

STR. $159-180$

BARTOLAC, A.

ZA MENE, LJUBAV JE... ku) odabrana osoba jedina kvalificirana za dodijeljenu joj ulogu (koncept ekskluzivnosti), drugim riječima jedina osoba koja nas može učiniti sretnima i potpunima, intimnost je uvid u "unutarnje ja" druge osobe i mehanizam zajedničkog razvoja (Štulhofer, 2005., 86).

Čudina-Obradović i Obradović (2006.) navode četiri skupine varijabli koje su se $u$ istraživanjima trajnosti i snage raznospolne ljubavi pokazale prediktivnim odrednicama ljubavi: rod, dob, privrženost roditeljima u ranom djetinjstvu i osobine ličnosti pojedinca. Pritom naglašavaju kako se provedena istraživanja odnose na sjevernoameričke i zapadnoeuropske sudionike, dok su u drugim dijelovima svijeta, uključujući i naše područje - deficitarna.

Istraživanja koja su ispitivala rodne razlike $\mathrm{u}$ romantičnosti tijekom vremena pokazala su nedosljedne rezultate. $U$ istraživanjima najčešće susrećemo Leeevu taksonomiju ljubavi (1977.), pa tako Dion i Dion (1993. a, b) opisuju rezultate nekoliko istraživanja provedenih $\mathrm{s}$ američkim studentima, a koja upućuju na rodne razlike u doživljavanju ljubavi. Studentice u njihovim istraživanjima redovito izvješćuju o većoj sklonosti storgičnom (prijateljskom) i pragmatičnom (praktičnom, realističnom) stilu ljubavi, dok studenti iskazuju više rezultate na mjerama romantičnosti i romantičnom idealizmu, kao i ludičkom (zaigranom) stilu ljubavi. Njihovi nalazi sukladni su dotadašnjim (npr. Bailey i sur., 1987.), kao i kasnijim istraživanjima (Hendrick i Hendrick, 2005.). Iz ovoga bi se moglo pretpostaviti da se očekuju romantičniji stavovi prema ljubavi od muških sudionika, dok bi žene mogle iskazivati veću realističnost. Nasuprot tome, druga istraživanja upućuju na više rezultate na skali romantičnosti u žena (studentica) $u$ međukulturalnom kontekstu, bez obzira na to pripadaju li indivdualističkom (SAD) ili kolektivističkom (Turska, Indija) okruženju (Medora i sur., 2002.). Ujedno u novijim istraživanjima nisu pronađene razlike između žena i muškaraca u izražavanju erotske i altruistične ljubavi (Hendrick i Hendrick, 2005.), dok su rezultati za manični stil ljubavi nekonzistentni (Dion i Dion, 1993.b; Hendrick i Hendrick, 2005.; Todosijević i sur., 2009.).

Knox je (1970.) istraživao postoje li razlike u doživljavanju romantične ljubavi s obzirom na dob, i to kod osoba koje su u kasnoj adolescenciji, unutar prvih pet godina braka, više od 20 godina $\mathrm{u}$ braku. Koristio se vlastitom Skalom stavova prema ljubavi, koja doživljaj ljubavi mjeri na kontinuumu od ekstremne romantičnosti do ekstremne realističnosti. Istraživanje je pokazalo da postoji jasna romantična orijentacija kod skupine adolescenata i jasna realistična orijentacija kod odraslih čiji brak traje do pet godina. Knox nagađa o razlozima adolescentne romantičnosti u stavu prema ljubavi i navodi da su mladi izloženiji romantičnim temama iz masovnih medija (fil- 
DRUŠ. ISTRAŽ. ZAGREB GOD. 21 (2012), BR. 1 (115),

STR. 159-180

BARTOLAC, A.: ZA MENE, LJUBAV JE...

1. Postavlja se pitanje je li liubav emocija ili motiv, s obzirom na to da postoje dokazi koji podržavaju obje teorije (Reis i Aron, 2008.). movi, popularna glazba, mladenački časopisi i sl.), te da je kod mladih prisutan manjak obvezivanja (adolescenti nemaju bračne / roditeljske odgovornosti niti prigodna socijalna očekivanja prisutna kod skupine ispitanika u braku). Prema tome, kako adolescenti odrastajući ulaze u mlađu odraslu dob, preuzimaju nove uloge sa snažnim socijalno-kulturološkim očekivanjima koja se odnose na preuzimanje odgovornosti prema sebi, obitelji i zajednici, stavovi se pomalo prilagođavaju i počinju primjećivati da ljubav možda ipak ne pobjeđuje sve. Jednako tako, u mlađoj dobi razmjena u smislu osiguravanja novih iskustava (posebice seksualnih) i uzajamnosti dobri su razlozi za održavanje veze (Schulman i Scharf, 2000.), što upućuje na osobito vrednovanje romantične vrste ljubavi. S druge strane, u starijoj dobi očekuje se podrška, ugodnost i brižnost, odnosno storgične, pragmatične i agapeične kvalitete ljubavi, koje više pripadaju području realističnijega stava.

Može li se ljubav izmjeriti? Istraživanja su učinila ljubav značajno manje misterioznom (Reis i Aron, 2008.), no interes za preispitivanje i razumijevanje ovoga motivacijsko-emocionalnog ${ }^{1}$ konstrukta (Fisher i sur., 2002.) ne prestaje. Razlozi mogu biti osobni, umjetnički ili znanstveni, no to ne umanjuje činjenicu da je ljubav nedvojbeno jedna od pojava koju povezujemo s ljudskosti.

Jedan od najranijih i možda najutjecajnijih upitnika za mjerenje dijadne privlačnosti jesu dvije Rubinove ljestvice. Skala ljubavi ispituje afilijativne i ovisničke potrebe, predispoziciju za pomoć te osjećaje ekskluzivnosti i apsorpcije (predanosti), dok Skala sviđanja sadrži dvije osobine: sličnost sebi i pozitivna procjena te poštovanje prema drugoj osobi (Rubin, 1970.). Navedenih pet sastavnica nalikuju Leeevoj tipologiji ljubavi: mania (ovisnost), agape (pomoć), eros (apsorpcija), pragma (poštovanje) i storge (sličnost). Upravo je navedena tipologija najviše istraživana uz pomoć ljestvice koju su kasnije konstruirali i dorađivali bračni par Susan i Clyde Hendrick (npr. Hendrick i sur., 1984.; Hendrick i Hendrick, 1986.; Cramer, 1993; Arnold i Thompson, 1996.; Todosijević i sur., 2009.). Iskustvo ljubavi u odnosu na partnera također je predmet interesa Hatfield i Sprecher (1986.), koje svojom ljestvicom ispituju strastvenost $\mathrm{u}$ odnosu na imenovanoga partnera.

Uvidom u literaturu stječe se dojam da je najproduktivnije vrijeme za konstrukciju skala koje bi ispitivale aspekte ljubavi bilo sedamdesetih i osamdesetih godina 20. stoljeća. Ipak, instrumenti koji ispituju ovaj konstrukt nastavljaju se razvijati, no vrlo se često zadržavaju na teorijskim temeljima koje su postavili Lee i Sternberg. Primjerice, Hendrick i sur. (1998.) dorađuju skraćeni oblik Skale stavova prema ljubavi, dok Sternberg (1997.) razvija svoju ljestvicu utemeljenu na triangularnoj teoriji ljubavi. 
DRUŠ. ISTRAŽ. ZAGREB GOD. 21 (2012)

BR. 1 (115)

STR. $159-180$

BARTOLAC, A.

ZA MENE, LJUBAV JE..
Mijenjaju li se s vremenom stavovi prema romantičnoj ljubavi? Vremena zasigurno nisu ista; vrijednosti i stavovi pod višestrukim su utjecajem kulture informacija koje pristižu sa sve raznolikijih i sve dostupnijih medija, socijalizacijski procesi događaju se na razinama koje su nekada bile nepojmljive; ljudi se upoznaju, komuniciraju i bestjelesno povezuju putem interneta, mijenjajući vlastite identitete ili stvarajući sasvim nove. Kako ovi trendovi djeluju na međuljudske odnose, očekivanja i doživljaj toga posebnog stanja koje je većina iskusila ili tek očekuje to iskustvo (Knox, 1970.), možemo pratiti tek povremenim ponavljanjem ovakvih istraživanja i provjerom međukulturalne stabilnosti ljestvica (Todosijević i sur., 2009.) kako bismo uvidjeli da li vrijeme i kontekst mijenjaju doživljaj ljubavi, njezinu važnost $i$ iskustvo.

\section{CILJ I PROBLEMI ISTRAŽIVANJA}

S obzirom na manjak istraživanja vezanih uz doživljaj ljubavi u našoj sredini, osnovni je cilj ovog istraživanja ispitati koliko romantičnom sudionici doživljavaju ljubav, koristeći se Upitnikom stavova prema ljubavi (Knox, 1969., prema Knox i Schacht, 2004., 47). Razlog odabira ovog instrumenta jest ispitivanje općega stava prema romantičnoj ljubavi, a ne stava prema određenoj osobi koja je objekt zaljubljenosti (što je uglavnom predmet ispitivanja drugih ljestvica), a kako bi se obuhvatio onaj dio uzorka sudionika koji trenutačno nije u vezi, odnosno koji trenutačno ne gaji romantične osjećaje prema drugoj osobi. Kako se radi o prvoj primjeni te skale u hrvatskim uvjetima, prije provođenja postupaka obradbe podataka u svrhu odgovora na probleme također se planiraju provjeriti osnovne metrijske osobine korištene ljestvice kako bi se provjerilo može li se $\mathrm{u}$ ovim uvjetima ljestvica tretirati kao jednodimenzionalan instrument te se sukladno tome prilagodila i obradba podataka.

Osim navedenog, predmet interesa ovog istraživanja odnosi se i na utvrđivanje razlike $\mathrm{u}$ romantičnosti stava prema ljubavi s obzirom na demografska obilježja sudionika. U ovom istraživanju kreće se od nulte hipoteze o rodnoj razlici među sudionicima, s obzirom na spomenutu nedosljednost u dosadašnjim istraživanjima vezanu uz ovaj podatak. Kako se istraživanja stava prema ljubavi uglavnom provode sa studentima, rijetko nailazimo na podatke o razlikama s obzirom na dob, pa su očekivanja zasnovana na pretpostavci da će mlađi sudionici biti romantičnijega stava (Knox i Sporakowski, 1968.; Knox, 1970.; Dion i Dion, 1993.b).

Odrednice ljubavi češće se istražuju i ti podaci su lakše dostupni. No, subjektivni doživljaj ljubavi prije ćemo susresti u svakodnevnom laičkom razgovoru ili psihoterapijskoj/savje- 
DRUŠ. ISTRAŽ. ZAGREB GOD. 21 (2012),

BR. 1 (115),

STR. 159-180

BARTOLAC, A.:

ZA MENE, LJUBAV JE... todavnoj razmjeni, nego li u istraživačkim nacrtima. Činjenica je da kvantitativne skale uvelike olakšavaju obradu podataka i donošenje zaključaka potkrijepljenih statističkim pokazateljima. Međutim, bez obzira na psihometrijske argumente vezane uz prihvatljivost skale, rezultate koje dobijemo možemo razmatrati samo kao grupne prosjeke. Kako je ljubav zasigurno vrlo subjektivan konstrukt, individualnost u odgovorima teško bi se mogla zahvatiti isključivim korištenjem skale. Stoga je na kraj upitnika dodana nedovršena rečenica $Z a$ mene, ljubav je... čija je namjera ispitati upravo taj osobni doživljaj ljubavi, te provjeriti uklapaju li se u kategorije definirane dosadašnjim istraživanjima (npr. Watts i Stenner, 2005.; Reis i Aron, 2008.; Milivojević, 2009.).

\section{METODOLOGIJA}

\section{Strukfura sudionika}

U istraživanju su sudjelovala 503 studenta/ice redovitih i izvan-

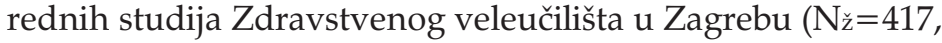
$\mathrm{Nm}=86$ ). Sudionici u ovom prigodnom uzorku prosječne su dobi od 27,18 godina $(\mathrm{SD}=9,00)$, od toga žene imaju prosječno 27,75 godina $(\mathrm{SD}=9,23)$, a muškarci 24,47 godina $(\mathrm{SD}=7,01)$, pri čemu se raspon dobi kreće od 18 do 58 godina. Najveći broj studenata nalazi se na prvoj godini studija $(66,5 \%)$, dok se njih 10,7\% nalazi na višim godinama studija (4. i 5.). Podjednako su odrastali u gradu (51,9\%), kao i na selu ili manjem mjestu $(48,1 \%)$, najčešće s oba roditelja (njih $88,1 \%$ ) koji žive (ili su do kraja života živjeli) u braku te se izjašnjavaju kao umjereno religiozni $(68,4 \%)$. U posljednjih godinu dana većina sudionika $(69,2 \%)$ bila je u ozbiljnoj vezi s jednom osobom, a $40,4 \%$ je barem neko vrijeme živjelo s partnerom. U vrijeme prikupljanja podataka njih 59,8\% živjelo je s obitelji ili sustanarima, a $31,6 \%$ s partnerom.

\section{Mjerni instrument}

Sudionici su za potrebe istraživanja ispunili originalni Upitnik stavova prema ljubavi (The Love Attitudes Scale, Knox, 1969., prema Knox i Schacht, 2004.), za čiju je uporabu dobivena pismena dozvola autora. Knox i Sporakowski (1968.) ponešto su modificirali ovu ljestvicu, no originalna verzija i dalje se nalazi u recentnijoj literaturi. Upitnik sadrži 30 izjava koje opisuju osobine romantične ljubavi, a rezultat se izražava na kontinuumu od romantičnoga do realističnoga stava. Čestice su prevedene na hrvatski jezik uz pomoć profesionalnoga prevoditelja za engleski jezik. Skala je Likertova tipa, gradacije od 1 do 4 , a ispituje slaganje s pojedinom tvrdnjom navedenom u upitniku (od uopće se ne slažem do potpuno se slažem). 
DRUŠ. ISTRAŽ. ZAGREB GOD. 21 (2012), BR. 1 (115)

STR. $159-180$

BARTOLAC, A.

ZA MENE, LJUBAV JE..
Najviši mogući zbroj ocjena iznosi 120 i označuje maksimalno slaganje sa svim tvrdnjama, odnosno potpuno romantičarski pogled na ljubav. Suprotno tome, zbroj od 30 bodova označuje potpuno odbacivanje romantičarskoga stava, odnosno vjerovanje da je ljubav konjugalna ili pragmatična.

Prije testiranja konstruktne valjanosti provjereno je jesu li korišteni podaci primjereni za analizu strukture. Dobivena vrijednost Kaiser-Meyer-Olkinova testa $(\mathrm{k}=0,86)$ upućuje na dovoljnu proporciju varijance u varijablama koja bi mogla biti uzrokovana faktorima u pozadini. Bartlettov test pokazao se statistički značajnim $\left(\chi^{2}=3192,91, p<0,001\right)$, što upućuje na korelacijsku matricu pogodnu za faktorizaciju. Izračunom ukupne varijance vidi se da čak 8 faktora ima karakterističan korijen $(\lambda)$ veći od 1 . Zajedno oni objašnjavaju gotovo $54,5 \%$ varijabilnosti originalnih varijabli, pri čemu prvi faktor obuhvaća 23 varijable. Hinkle i Sporakowski (1975.) dobili su sličan nalaz s osmofaktorskom strukturom analizirajući prilagođenu Knox-Sporakowski ljestvicu, pri čemu je prvi faktor okupljao 25 od 29 čestica, što je navelo autore na to da potvrde jednodimenzionalnost ljestvice. Ipak, čak i nakon kosokutne rotacije, izdvojivši tri međusobno korelirana faktora, autori predlažu izračun ukupnog rezultata sumiranjem svih čestica triju izdvojenih faktora ili dodatno učvršćivanje hipoteze o tri faktora testiranjem na heterogenijim uzorcima sudionika. Kako je u navedenom primjeru, jednako kao i u ovom istraživanju, upotrijebljen prigodan uzorak koji čine studenti, potvrdu faktorske strukture trebalo bi tražiti u budućim istraživanjima.

Provjerom pouzdanosti Upitnika stavova prema ljubavi utvrđen je relativno visok koeficijent unutarnje konzistencije $(\alpha=0,870)$. Metodom diobe testa dobiven je nešto niži Spearman-Brownov koeficijent pouzdanosti $(\mathrm{rtt}=0,797)$ od onih koje je dobio Knox (1970.) na 3 skupine po 100 sudionika koje su se razlikovale po bračnom statusu ( $\mathrm{rtt}=0,82-0,87)$. Pretpostavka je da su Knoxovi sudionici homogenijega stava, s obzirom na to da su bili u partnerskoj vezi.

Na početku upitnika nalaze se pitanja vezana uz opće demografske podatke, koji obuhvaćaju sljedeće varijable: spol, dob, dosadašnji najviši završeni stupanj obrazovanja, godina studija, veličina mjesta u kojem su sudionici živjeli do punoljetnosti, struktura obitelji tijekom odrastanja (odrasli s oba roditelja, s jednim roditeljem ili bez roditelja), bračni status roditelja (u braku, izvanbračnoj zajednici ili ne žive zajedno, ali još uvijek vjenčani / nisu se nikada vjenčali / ili rastavljeni), s kim sudionici trenutačno žive (s roditeljima, bratom / sestrom, partnerom, sa sustanarom, sam/a), smatraju li se religioznim, jesu li zadnju godinu bili u partnerskoj vezi (ako da, s koliko osoba), jesu li ikada živjeli s partnerom (ako da, koliko dugo) 
DRUŠ. ISTRAŽ. ZAGREB GOD. 21 (2012),

BR. 1 (115),

STR. 159-180

BARTOLAC, A.:

ZA MENE, LJUBAV JE...

\section{Postupak}

\section{REZULTATI}

\section{Kvantitativna obradba podataka}

Kako je provjerom konstruktne valjanosti utvrđeno da je 76,67\% čestica upotrijebljenog Upitnika stavova prema ljubavi obuhvaćeno jednim faktorom, prilikom obradbe rezultata ta je činjenica uzeta u obzir te je za svaki statistički izračun provjereno da li se konačan rezultat razlikuje s obzirom na to je li korišteni kompozit zavisne varijable sastavljen od svih čestica ili 23 čestice unutar prvoga faktora. Kako se ni jedan konačni rezultat nije razlikovao s obzirom na taj kompozit, $\mathrm{u}$ radu su predočeni rezultati za ukupan zbroj rezultata svih čestica, jer se radi o prigodnom uzorku sudionika, pa se ne može pouzdano tvrditi da bi dobivena faktorska struktura bila univerzalna za heterogeniji uzorak.

Normalitet distribucije rezultata dobivenih Upitnikom stavova prema ljubavi provjeren je Kolmogorov-Smirnovljevim testom, kojim je utvrđeno da se dobivena distribucija ne razlikuje značajno od normalne $(\mathrm{z}=0,652, \mathrm{p}=0,788, \mathrm{~N}=503)$.

Prvi problem $\mathrm{u}$ ovom istraživanju bio je ispitati koliko su stavovi studenata romantični prema ljubavi, služeći se Upitnikom stavova prema ljubavi Knox-Sporakowskoga. Mogući raspon rezultata proteže se od 30 (izrazito pragmatično) do 120 (izrazito romantično) bodova, no u ovom uzorku raspon rezultata kretao se od 47 do 115 bodova. Uvidom u deskriptiv- 
DRUŠ. ISTRAŽ. ZAGREB GOD. 21 (2012),

BR. 1 (115),

STR. $159-180$

BARTOLAC, A.:

ZA MENE, LJUBAV JE.. vidi se da ne postoje sudionici koji su potpuno romantični ili pragmatični, no kako se 75 bodova nalazi u sredini skale i označuje stav koji nije pretežno romantičan niti pragmatičan, može se reći da su sudionici iskazali u prosjeku umjereno romantičan stav prema ljubavi.

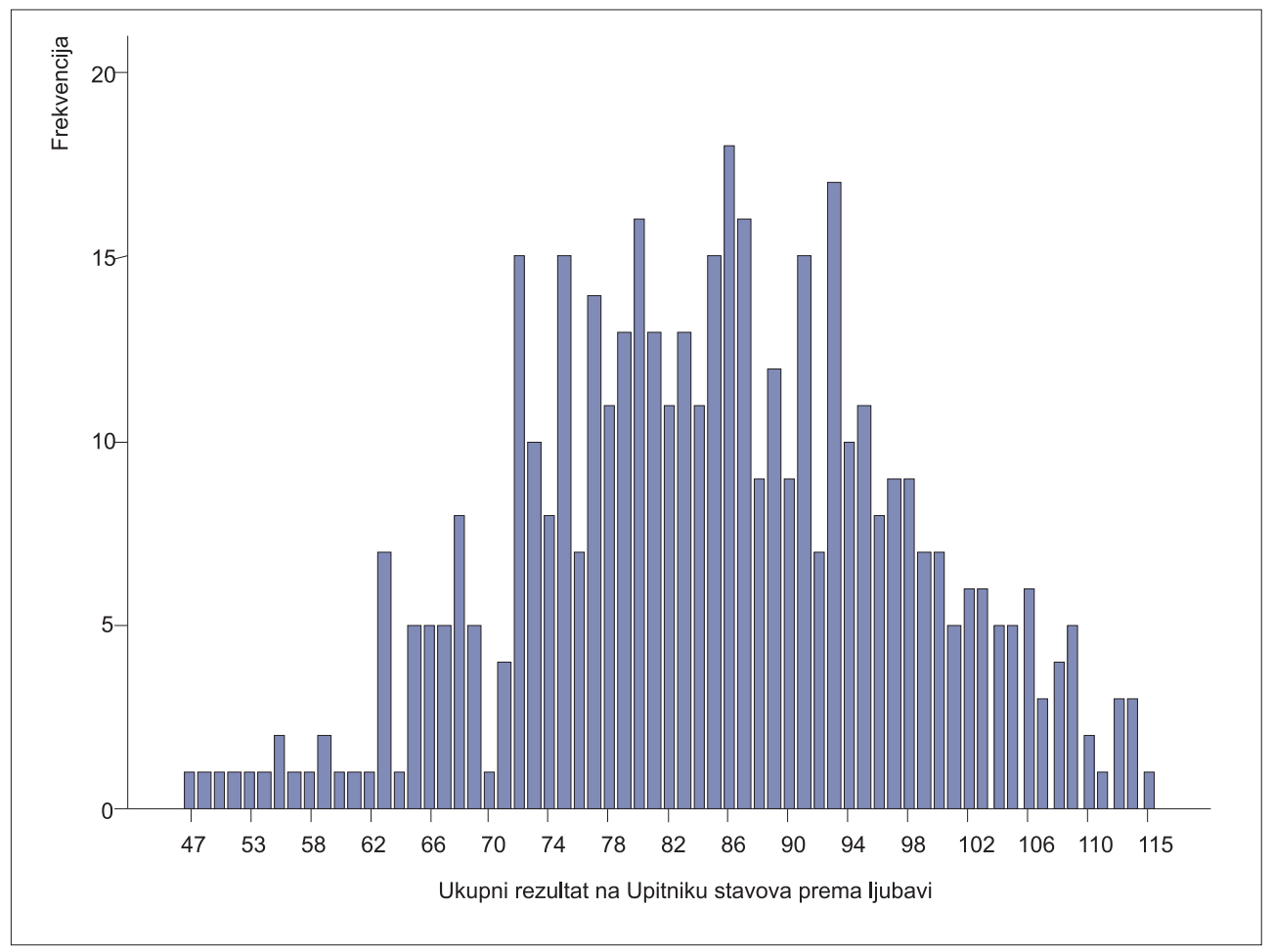

i) SLIKA 1

Grafički prikaz distribucije rezultata na Upitniku stavova prema liubavi $(N=503)$
Na pojedinim česticama vidi se veće ili manje slaganje s izjavama koje opisuju ljubav ili ponašanje vezano uz ljubav. Većina sudionika slaže se s izjavom da za većinu ljudi negdje postoji njihov idealni par $(85,5 \%)$ i da u većini slučajeva ljudi znaju kada sretnu pravog partnera $(79,9 \%)$. Također većina smatra da ljubav nije pitanje uma nego srca: Kada te ljubav pogodi, znati ćeš $(88,1 \%)$; Kada si zaljubljen, više si motiviran osjećajima nego razumom $(90,2 \%)$. Vjeruju i da ljubav pomaže u rješavanju problema (Dokle god nekoga voliš, moći ćeš riješiti sve probleme s tom osobom $(77,4 \%))$, kao i da obrazovanje i socijalna okolina ne utječu na ljubav (Dokle god se dvoje ljudi voli, stupanj njihova obrazovanja ne igra nikakvu ulogu $(71,2 \%)$; Možeš voljeti nekoga, iako ti se ne sviđaju njegovi/njezini prijatelji $(87,9 \%))$. Ujedno većina smatra da je ljubav preduvjet za brak (Ljudi se ne bi trebali vjenčati ako nisu zaljubljeni (74\%); Za sreću je nužno biti zaljubljen/a u onoga kime ćě̌ se vjenčati $(80,1 \%))$.

S druge strane, manji broj sudionika slaže se s izjavom da ljubav dolazi samo jednom u životu (38,5\%). Smatraju da je za lju- 
DRUŠ. ISTRAŽ. ZAGREB GOD. 21 (2012), BR. 1 (115),

STR. 159-180

BARTOLAC, A.:

ZA MENE, LJUBAV JE...

(1) TABLICA 1

Deskriptivna statistika za Upitnik stavova prema liubavi s obzirom na sociodemografske varijable, s pripadajućim rezultatima t-testa ili analize varijance bav ipak potrebno vrijeme upoznavanja, pa je slaganje sa sljedećim izjavama manje jednoglasno: Nije važno ako se vjenčate iako se poznajete tek kratko vrijeme, važno je da se volite (48,1\%); Ljubav na prvi pogled najčěšć je najdublja i najustrajnija vrsta ljubavi (42,9\%); Hoćeš li voljeti neku osobu, znaš već nakon što je poznaješ kratko vrijeme $(42,5 \%)$.

Drugi problem odnosio se na usporedbu romantičnosti stava prema ljubavi s obzirom na demografska obilježja sudionika. Serijom t-testova i analiza varijance (Tablica 1 ) provjerene su razlike u stavu prema romantičnoj ljubavi s obzirom na spol, dob, mjesto odrastanja, cjelovitost obitelji u kojoj su odrasli, bračni status roditelja, s kim žive, religioznost, jesu li u partnerskoj vezi, iskustvo života s partnerom te koliko su sretni u trenutačnoj vezi. Sudionici ovog istraživanja značajno su se razlikovali u svojem stavu kada su bili podijeljeni u skupine s obzirom na veličinu mjesta $\mathrm{u}$ kojem su odrastali do punoljetnosti te s obzirom na iskazani stupanj religioznosti. Razlike $\mathrm{u}$ ostalim varijablama nisu se pokazale značajnima.

\begin{tabular}{|c|c|c|c|c|c|c|c|}
\hline Varijable & Skupine & $\mathrm{N}$ & M & SD & $\mathrm{df}$ & $t / F$ & $\mathrm{p}$ \\
\hline Spol & $\begin{array}{l}\text { Žene } \\
\text { Muškarci }\end{array}$ & $\begin{array}{r}417 \\
86\end{array}$ & $\begin{array}{l}82,92 \\
82,40\end{array}$ & $\begin{array}{l}12,54 \\
12,02\end{array}$ & 501 & 0,351 & 0,726 \\
\hline Dob & $\begin{array}{l}\text { Mlađi }(\leq 29) \\
\text { Stariji }(\geq 30)\end{array}$ & $\begin{array}{l}345 \\
157\end{array}$ & $\begin{array}{l}82,26 \\
84,14\end{array}$ & $\begin{array}{l}12,065 \\
13,195\end{array}$ & 500 & $-1,570$ & 0,117 \\
\hline Mjesto odrastanja & $\begin{array}{l}\text { Selo } \\
\text { Grad }\end{array}$ & $\begin{array}{l}242 \\
261\end{array}$ & $\begin{array}{l}84,18 \\
81,58\end{array}$ & $\begin{array}{l}12,07 \\
12,68\end{array}$ & 501 & 2,352 & 0,020 \\
\hline Cjelovitost obitelji & $\begin{array}{l}\mathrm{S} \text { oba roditelja } \\
\mathrm{S} \text { jednim roditeljem }\end{array}$ & $\begin{array}{r}443 \\
56\end{array}$ & $\begin{array}{l}82,87 \\
82,27\end{array}$ & $\begin{array}{l}12,433 \\
12,761\end{array}$ & 489 & 0,341 & 0,733 \\
\hline Roditelji u braku & $\begin{array}{l}\mathrm{Da} \\
\mathrm{Ne}\end{array}$ & $\begin{array}{r}427 \\
64\end{array}$ & $\begin{array}{l}82,99 \\
81,02\end{array}$ & $\begin{array}{l}12,413 \\
12,402\end{array}$ & 489 & 1,186 & 0,236 \\
\hline Živim s & $\begin{array}{l}\text { Roditeljima } \\
\text { Partnerom } \\
\text { Sustanarom } \\
\text { Sam/a }\end{array}$ & $\begin{array}{r}186 \\
159 \\
111 \\
38\end{array}$ & $\begin{array}{l}82,46 \\
83,28 \\
83,63 \\
80,44\end{array}$ & $\begin{array}{l}13,036 \\
13,123 \\
10,170 \\
12,715\end{array}$ & $3 / 490$ & 0,746 & 0,525 \\
\hline Religioznost & $\begin{array}{l}\text { Nimalo } \\
\text { Umjereno } \\
\text { Izrazito }\end{array}$ & $\begin{array}{r}78 \\
344 \\
81\end{array}$ & $\begin{array}{l}80,01 \\
82,45 \\
87,14\end{array}$ & $\begin{array}{l}12,17 \\
12,27 \\
12,50\end{array}$ & $2 / 500$ & 6,405 & 0,002 \\
\hline U vezi & $\begin{array}{l}\mathrm{Da} \\
\mathrm{Ne}\end{array}$ & $\begin{array}{r}465 \\
33\end{array}$ & $\begin{array}{l}82,61 \\
86,22\end{array}$ & $\begin{array}{l}12,428 \\
11,723\end{array}$ & 496 & 2,613 & 0,107 \\
\hline Život s partnerom & $\begin{array}{l}\mathrm{Da} \\
\mathrm{Ne}\end{array}$ & $\begin{array}{l}359 \\
136\end{array}$ & $\begin{array}{l}82,84 \\
83,11\end{array}$ & $\begin{array}{l}12,068 \\
13,473\end{array}$ & 493 & $-0,218$ & 0,827 \\
\hline Sreća u vezi & $\begin{array}{l}\text { Slabo } \\
\text { Umjereno } \\
\text { Jako }\end{array}$ & $\begin{array}{r}47 \\
113 \\
192\end{array}$ & $\begin{array}{l}82,25 \\
81,46 \\
83,65\end{array}$ & $\begin{array}{l}13,326 \\
13,712 \\
12,115\end{array}$ & $2 / 349$ & 1,086 & 0,339 \\
\hline
\end{tabular}


DRUŠ. ISTRAŽ. ZAGREB GOD. 21 (2012), BR. 1 (115)

STR. $159-180$

BARTOLAC, A.:

ZA MENE, LJUBAV JE..
Kako se vidi iz Tablice 1, sudionici odrasli na selu ili u malom mjestu (do 10000 stanovnika) izražavaju romantičniji stav od sudionika odraslih u gradu. Također, rezultat jednostavne analize varijance pokazuje da su izrazito religiozni sudionici značajno romantičnijega stava od onih koji nisu religiozni (post-hoc Scheffe $=-0,365, p=0,003$ ), kao i od umjereno religioznih sudionika (post-hoc Scheffe $=-0,253, p=0,011$ ).

\section{Kvalitativna obradba podataka}

Treći problem odnosio se na ispitivanje osobnoga doživljaja ljubavi sudionika, koristeći se subjektivnim izjavama o tome što ljubav znači pojedinom sudioniku. Od ukupno 503 sudio-

(1) TABLICA 2

Teme koje objedinjuju izjave o doživliaju liubavi (Za mene, liubar je .... nika, svoj komentar ostavilo je njih 89,7\%. Obradbi dobivenih podataka pristupilo se otkrivanjem obrazaca koji se pojavljuju u izjavama sudionika, a koji su kodiranjem po svojoj sličnosti svrstani u teme (Tablica 2).

\section{OSJEĆAJ}

... predivan, najljepši osjećaj; sreće, zadovoljstva, pripadnosti, mira, radost, sigurnost, spokoj, zadovoljstvo, smirenost, poletnost, osjećaj da možeš svladati sve teškoće, osjećaj želje i vrijednosti onoga što zajedno radite, zajedništvo, osjećaj duboke povezanosti empatije; biti smiren, osjećati se voljeno i sigurno, ispunjenost, prihvaćanje, uzbuđenje

\section{PARTNERSKA LJUBAV}

... moj dečko kojeg volim više od ičeg u životu, moj suprug pun razumijevanja i topline, moja supruga; vjernost i dijeljenje svega što imamo sa svojim supružnikom; poštovanje, razumijevanje i povjerenje između dvije osobe koje bez obzira na loše stvari u životu biraju da budu jedna uz drugu; kada prema nekoj osobi osjećam više nego prema drugima, tj. kada bi sve za njega napravila; kada znam da tu osobu ne želim izgubiti i kada je ne želim dijeliti ..., kad me partner voli bez obzira na sve, kad vidi samo mene; ON (razumijevanje, sigurnost, utočište, strast, žudnja, čežnja, san ...)

\section{LJUBAV PREMA DJETETU/OBITELJI}

... sve na svijetu: moja obitelj, suprug i naše dijete, ljubav majke i djeteta

\section{PONAŠANJE}

...tolerancija, podrška, suradnja; razgovor, brižnost, podupiranje, poštovanje, oprost, trud, strpljenje, ulaganje, međusobno darivanje, prijateljstvo tijekom cijeloga života, mnogo kompromisa i prilagodbe, sitne nježnosti, poljubac, brižnost, utjeha, oslonac, iskrenost, pomaganje, podrška, hrabrenje, duboko razumijevanje, ustrajnost, lojalnost, svađa i mirenje

\section{PRIHVAĆANJE}

... prihvaćanje moje osobnosti, poštivanje slobode izbora (posao, obrazovanje, majčinstvo), prihvaćanje osobe onakva kakva jest; spremnost prihvatiti osobu kakva ona zapravo jest, a ne kako je mi vidimo ili što bismo željeli da ona bude; kada nekog prihvaćaš sa svim njegovim manama i vrlinama 


\section{ALTRUIZAM/DAVANJE}

... kada daješ, a ne očekuješ natrag nužno isto, već kada uživaš da je netko zbog tebe sretan i voljen; sve što činiš za osobu koju voliš, kako bi je usrećio

\section{RAZMJENA/DAVANJE-PRIMANJE}

... dar: što je više daješ, više je primaš; voljeti i biti voljen; kada maksimalno daješ i ulažeš, ali isto tako da ti se to vraća; uzajamno poštovanje i razumijevanje

\section{TJELESNA}

... kemijski proces, seks, mladenački hormoni; imam želju poljubiti tu osobu, zagrliti, osjetiti; kad ti netko strastveno nedostaje, navala testosterona, erotski užitak

\section{DUHOVNA/OSOBNI RAST}

... nešto nadnaravno; energija koja ima uporište u Bogu; duhovna smirenost i pokretačka snaga, ljubav je najveći božji dar čovjeku; trenutačno ono što me drži na životu; nešto istinsko, duboko, strpljivo, povjerljivo; I. poslanica Korinćanima 13; osjećaj koji te ispunjava i budi ono najbolje u tebi

\section{UGODNA/IDEALIZAM}

... vrlina nad vrlinama, osnova svega u životu; najsavršenija emocija; blagostanje, nešto najljepše na svijetu što se osobi može dogoditi; jedini osjećaj zbog kojeg vrijedi živjeti; najviša na ljestvici emocija koja pokreće svijet i potiče na dobro; osmijeh s kojim se budimo svako jutro; sila koja pokreće svijet; život; sve

\section{NEUGODNA/RAZOČARANJE}

... možda i ne postoji; samo grijeh i ništa više; razočaranje?; mit!; slijepa; sranje!; trenutno ne vjerujem u ljubav; precijenjena; bacati bisere pred svinje; pomućenje pameti i razuma; ljubav je glupost; ma koja ljubav ?!!

\section{ZALJUBLJENOST}

Ljubav je ... nešto više od zaljubljenosti - podrška, prijateljstvo i razumijevanje uz emocionalni osjećaj zaljubljenosti; nešto što te ostavi bez daha u očekivanju susreta, a s vremenom toplo iščekivanje dopunjuje i razumijevanje; različita od zaljubljenosti! Zaljubljenost je osjećaj, ljubav - odnos; osjećaj koji slijedi kada zaljubljenost splasne

U skladu s podacima iz literature, na osnovi predočenih tema definirane su osnovne očekivane kategorije grupiranja podataka: ljubav kao emocija, motivacija, odnos i ponašanje (Reis i Aron, 2008.; Milivojević, 2009.). Teme su se uklopile u predefinirane kategorije, onako kako je prikazano na Slici 2.

Dodatno su analizirane kategorije partnerske ljubavi Wattsa i Stennera (2005.). Za svaki navedeni faktor mogu se pronaći primjeri izjava sudionika ovog istraživanja koje se uklapaju u opis pojedinoga faktora kako navode spomenuti autori (Tablica 3). 
DRUŠ. ISTRAŽ. ZAGREB

GOD. 21 (2012),

BR. 1 (115)

STR. 159-180

BARTOLAC, A.:

ZA MENE, LJUBAV JE...

- SLIKA 2

Kategorije koje objedinjuju teme o osobnom doživljaju ljubavi

(1) TABLICA 3

Usporedba faktora partnerske ljubavi Wattsa i Stennera (2005.) i izjava sudionika ovog istraživanja

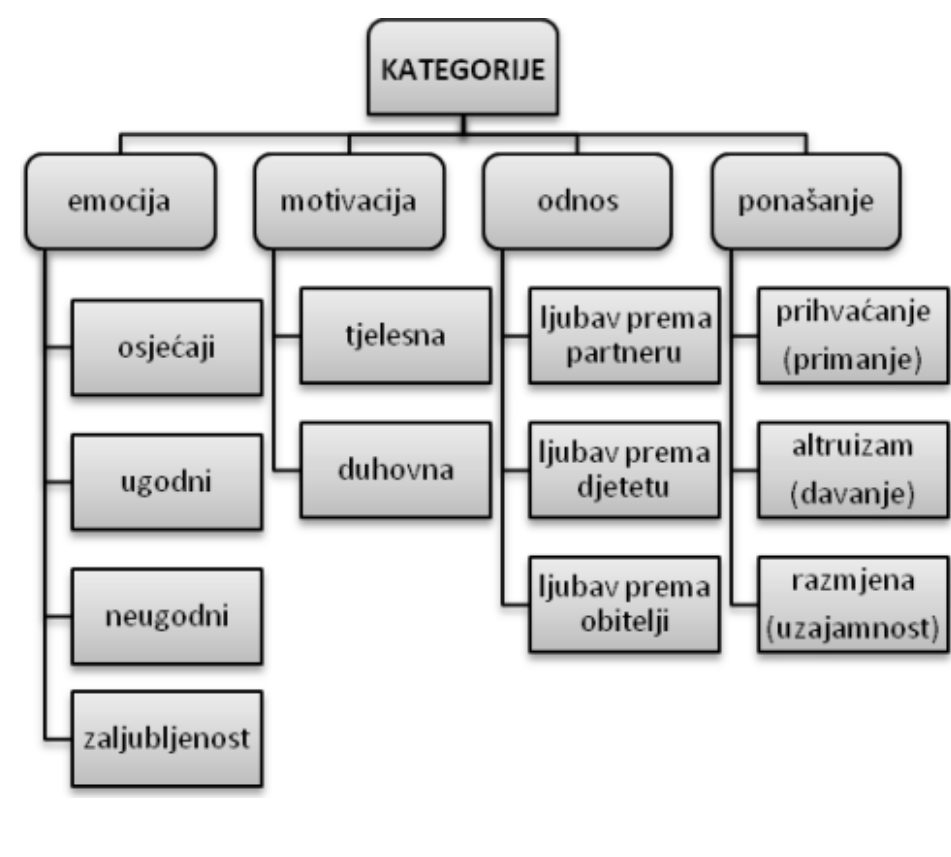

Faktori partnerske ljubavi Watts i Stenner (2005)

Primjeri izjava o doživljaju ljubavi u skladu s opisom navedenih faktora

Uzajamno povjerenje, uvažavanje i podrška

Uzajamno poštovanje i razumijevanje, prihvaćanje osobe onakva kakva jest, tolerancija, podrška, razgovor, poštovanje, trud, strpljenje, kompromis

Kupidova strijela Strast, žudnja, mladenački hormoni, slijepa, pomućenje pameti i razuma

Hedonistička ljubav Sreća, zadovoljstvo, seks, erotski užitak, imam želju poljubiti tu osobu ... osjetiti je, život

Demistificirana ljubav

Komunikacija, duboko razumijevanje, precijenjena, kompromis, tolerancija, kada nekoga prihvaćaš sa svim njegovim manama i vrlinama

Ljubav kao konačna povezanost i dubok osjećaj

Najljepši osjećaj, zadovoljstvo, spokoj, osjećaj duboke povezanosti, biti smiren, ispunjenost, najsavršenija emocija, emocija koja pokreće svijet

Ljubav kao transformirajuća pustolovina

Prilagodba, iskrenost, prihvaćanje moje osobnosti, poštivanje slobode izbora (posao, obrazovanje, majčinstvo), nešto istinsko

Od Kupidove strijele do obvezujućeg odnosa

Osjećaj koji slijedi kada zaljubljenost splasne, nešto što te ostavi bez daha u očekivanju susreta, a s vremenom ... dopunjuje i razumijevanje

Od Kupidove strijele do prijateljstva

Prijateljstvo tijekom cijeloga života, ... podrška, prijateljstvo, razumijevanje uz emocionalni osjećaj zaljubljenosti, oslonac, sigurnost

Dijadni partnerski odnos

Zajedništvo, osjećati se voljeno i sigurno kada maksimalno daješ i ulažeš, ali isto tako da ti se vraća, uzajamno poštovanje i razumijevanje, vjernost i dijeljenje svega što imamo sa svojim supružnikom

Analizirana je i učestalost pojavljivanja pojedinih pojmova koje sudionici povezuju s osobnim doživljajem ljubavi (Slika 3). Najučestaliji pojam koji opisuje ljubav za sudionike jest razumijevanje, a nakon toga sreća, poštovanje i kompromis. 
$\rightarrow$ SLIKA 3

Frekvencije pojmova sadržanih u izjavama o doživliaju ljubavi (Za mene liubar je ...), za $f>4$

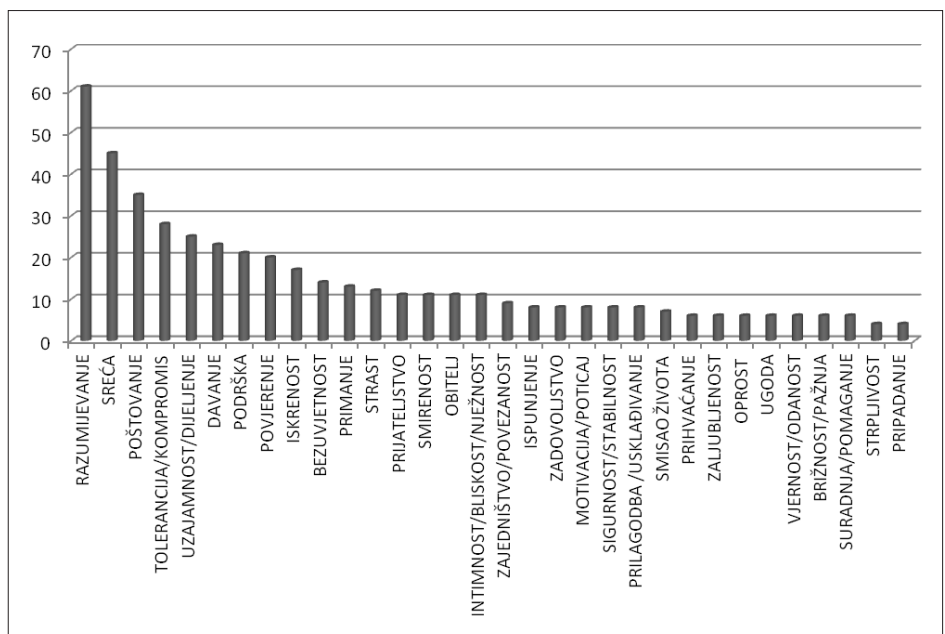

Osim pojmova navedenih u grafičkom prikazu, javljaju se i pojmovi koji su zastupljeni s nižim frekvencijama ( $f \leq 4)$, no ipak su ilustrativni, primjerice: ljubav je ekskluzionost, razgovor i dopunjavanje s partnerom, osjećaj potpunosti, kompatibilnost i sklad, ljubav je vječna, ali i žrtva, zajedničko planiranje budućnosti, suosjećanje / empatija, pripadanje, osobni rast, izazov, ustrajnost, ljubav je vrijedna, humor, vrlina, utjeha, dobročinstvo, zahtijeva trud, zrelost, ona je privlačnost, preplavljenost, pouzdanost, blagost i opuštenost.

\section{RASPRAVA}

Osim recentnog istraživanja Todosijevića i suradnica (2009.) te rada etnologinje Škokić (2004.), čini se da se kod nas i u zemljama našeg okružja ljubav kao fenomen rijetko istražuje, iako se interes za ovu temu u svijetu u zadnjem desetljeću proširio (npr. Masuda, 2003.; Watts i Stenner, 2005.; Neto, 2007.). Pritom su stilovi i odrednice ljubavi najčešći predmet istraživanja, dok je percepcija ljubavi (u ovom slučaju romantične ljubavi) vrlo rijetko istraživano područje.

\section{Odrednice stava prema ljubavi}

Da bismo provjerili povezanost osobina sudionika i sociodemografskoga konteksta u kojem se nalaze s doživljajem romantične ljubavi, 503 studenta redovitih i izvanrednih zdravstvenih studija zamoljeni su da ispune Knoxov Upitnik stavova prema ljubavi. Prosječan stav prema ljubavi cijele skupine sudionika izražen je kao umjereno romantičan $(\mathrm{M}=82,83)$. Iako neka istraživanja upućuju na razliku u stavovima u odnosu na rod i dob (Knox i Sporakowski, 1968.; Knox, 1970.; Hinkle i Sporakowski, 1975.; Dion i Dion, 1993.b), ta se razlika u ovom istraživanju nije pokazala značajnom ni po jednom krite- 
DRUŠ. ISTRAŽ. ZAGREB GOD. 21 (2012), BR. 1 (115)

STR. $159-180$

BARTOLAC, A. ZA MENE, LJUBAV JE... riju. U cijelom uzorku stav žena prema romantičnoj ljubavi nije se razlikovao od stava muškaraca $(\mathrm{t}=0,351, \mathrm{df}=501, \mathrm{p}>0,05)$. Činjenica je da u uzorku prevladavaju sudionice, što je očekivana rodna struktura uzorka s obzirom na to da je prikupljanje podataka provedeno u edukacijskoj ustanovi koja obrazuje studente za pomagačka zdravstvena zanimanja, za koja veći interes tradicionalno pokazuju žene. Može se pretpostaviti da bi se uzorak sudionika obuhvaćen ovim istraživanjem razlikovao od uzoraka studenata drugih studija (primjerice, tehničkih ili prirodoslovnih) o brižnoj ljubavi, jer je moguće da izbor studija odražava i preferencije $u$ socijalnom ponašanju. No romantična ljubav usmjerena na jednu osobu, (potencijalnoga) partnera, vjerojatno je obilježje gotovo svake osobe bez obzira na odabir struke, iako bi tu povezanost trebalo bolje istražiti.

U skladu s uvodno navedenim istraživanjima, očekivano je da će sudionici u mlađoj dobnoj skupini iskazivati veću prosječnu sklonost romantičnijem gledanju na ljubav. Iako se $28,9 \%$ sudionika nalazi u rasponu godina od 30 do 58 , nije utvrđena značajna razlika u stavu između mlađih i starijih sudionika. Značajna razlika ne nalazi se ni u novijim istraživanjima (npr. Todosijević i sur., 2009.), pa valja utvrditi je li takav rezultat zaista stabilan na dobno heterogenijem uzorku sudionika.

Kako je navedeno, u ovom uzorku sudionici zastupaju umjereno romantičan stav i takav nalaz može odražavati ravnotežu između individualističkoga, romantiziranog stava te manje romantiziranoga doživljaja ljubavi u skladu s kolektivističkom tradicijom. Promjene u političko-kulturološkim normama i nagla promjena vrijednosti, kao što su zajedništvo i kolektivizam u individualizam i konzumerizam, zacijelo je utjecala na promjenu u stavovima i ponašanjima vezanima uz socijalne odnose, osobito mladih ljudi. U takvu individualističkom društvu slabe i pooršne društvene veze, natjecanje i stalne međusobne usporedbe otežavaju stvaranje dubljih i prisnijih odnosa, pa su istinski, romantični odnosi cijenjeni jer pružaju emocionalnu toplinu i sigurnost te štite od izolacije i hladnoće okružja (Čudina-Obradović i Obradović, 2006., 17). Stoga je neočekivano što je usporedbom srednjih vrijednosti (Tablica 1) dobiven nalaz koji pokazuje da su studenti koji su odrastali na selu ili u manjim mjestima (očekujući kolektivistički duh zbog veće socijalne povezanosti u manjoj sredini) romantičniji od onih koji su odrasli u gradovima (u kojima je očekivana idealizacija romantičnih odnosa zbog veće otuđenosti i površnosti u interakciji). Moguće objašnjenje vezano je uz prevladavajući materijalizam, koji je sve prisutniji, osobito u mladih koji odrastaju u gradu, što čini njihove stavove pragmatičnijim i racionalnijim. Sudionici odrasli 
DRUŠ. ISTRAŽ. ZAGREB GOD. 21 (2012),

BR. 1 (115),

STR. 159-180

BARTOLAC, A.:

ZA MENE, LJUBAV JE... na selu pokazali su se romantičnijima možda zbog tradicijski većega vrednovanja odnosa (zajedništva) i emocija nego materije. Čini se da se stav prema romantičnosti u novih generacija, koje su izložene drugim socioekonomskim okolnostima, kao što su globalizacija putem interneta i medija, materijalizam i ekonomska kriza, neizvjesnost vezana uz budućnost i zapošljavanje, a samim tim i zasnivanje obitelji, mijenja.

Izrazito religiozni sudionici iskazali su značajno romantičniji stav prema ljubavi od sudionika koji se izjašnjavaju kao umjereno ili nimalo religiozni (Tablica 1). Ako se izostavi komponenta tjelesne privlačnosti koja prati romantičnu ljubav, možebitni razlog ove razlike mogao bi se pronaći u sličnosti psihološko-duhovnoga doživljaja romantične ljubavi s onim religioznim. Istaknuta karakteristika romantične ljubavi upravo je idealiziranje (željenoga) partnera uz zanemarivanje njegovih (ili njezinih) neprivlačnih osobina, navika ili ponašanja te socijalnoga ili materijalnoga statusa. Primjeri za tu tvrdnju mogu se pronaći u česticama upotrijebljenog upitnika stavova prema ljubavi koje opisuju zajedništvo s partnerom zasnovano isključivo na ljubavi kao emociji (npr. Zajednički interesi zaista nisu važni, dok god ste iskreno zaljubljeni, prilagodit ćete se; Kada si zaljubljen, nije važno što tvoj partner radi, voljet ćeš ga u svakom slučaju; Dokle god se dvoje ljudi voli, stupanj njihova obrazovanja ne igra nikakvu ulogu; Možeš voljeti nekoga iako ti se ne sviđaju njegovi I njezini prijatelji; Razlog većine razvoda jest manjak ljubavi, a ne nemogućnost prilagodbe). Prema navedenim obilježjima, romantična komponenta ljubavi vrlo je slična univerzalnim religijskim temeljima, koji naglašavaju uzvišenu ljubav bez uvjetovanja i racionalizacije. Moguće je da izrazito religiozni sudionici pridaju veće značenje emocionalnom i duhovnom aspektu ljubavi kao ključnim razlozima za partnerstvo, za razliku od manje religioznih, koji su pragmatičnijega stava. Naravno, ovu bi pretpostavljenu povezanost trebalo bolje istražiti.

Kako se u ovom istraživanju, ali i u novijim istraživanjima vezanim uz ovu temu, većina sociodemografskih varijabli nisu istaknule kao značajne odrednice stava prema romantičnoj ljubavi, preporuka za buduća istraživanja ove teme svakako je uključivanje novih čimbenika, kao što su, primjerice, dimenzija individualizam - kolektivizam, osobine ličnosti ili rana emocionalna privrženost.

\section{Osobni doživljaj ljubavi}

Na kvalitativnoj razini interes ovog istraživanja usmjeren je na osobni doživljaj ljubavi sudionika nedovršenom rečenicom ( $\mathrm{Za}$ mene, ljubav je ...), kako bi se sadržajnije utvrdila širina shvaćanja pojma ljubavi kod sudionika istraživanja. Sudionici su 
DRUŠ. ISTRAŽ. ZAGREB GOD. 21 (2012), BR. 1 (115)

STR. $159-180$

BARTOLAC, A. ZA MENE, LJUBAV JE.. ljubav opisali slobodnim iskazivanjem osobnog iskustva i doživljaja. Na taj način stečen je uvid $u$ doživljenu višeslojnost ove kompleksne emocije. Iako su izjave o ljubavi grupirane $u$ jedanaest tema (Tablica 2), sadržajno se mogu uočiti razlike koje prevladavaju u pojedinim iskazima. Može se primijetiti kako sudionici osobito naglašavaju odnos s drugom osobom i kroz taj odnos (i prihvaćenost unutar odnosa) vrednuju kvalitetu ljubavi. Partner (i/ili obitelj) u središtu su tog odnosa, a uzajamno razumijevanje, poštovanje, tolerancija i kompromis temelji su za taj odnos. Ovdje je očito da se na odnosu mora mnogo raditi i mnogo ulagati kako bi on opstao. I različiti načini i vrste ponašanja koje pripadaju ljubavnom odnosu ulaze u definiciju ljubavi (uzajamnost), kao i različite kvalitete ljubavi: altruizam, tjelesna, duhovna, idealistična, skeptična, ekskluzivna.

Navedene teme dobro su se uklopile u veće kategorije opisa ljubavi (ljubav kao emocija, motivacija, odnos i ponašanje), kako se vidi na Slici 2. Iz toga se može zaključiti da sudionici ljubav doživljavaju kao kompleksnu emociju (sastoji se i od ugodnih i od neugodnih osjećaja), motiviranu tjelesnim i duhovnim potrebama, koja u partnerskom smislu započinje zaljubljenošću, da bi se zatim razvijala u odnos obilježen jednostranim ili uzajamnim ponašanjima davanja i primanja. Stariji sudionici koji imaju vlastitu obitelj osobito naglašavaju ljubav prema djetetu kao posebnu emociju, koja po svojoj kvaliteti pripada brižnoj, a ne romantičnoj vrsti ljubavi, što ne umanjuje njezin intenzitet.

U Tablici 3 prikazano je osam subjektivnih, holističkih iskustava (faktora) partnerske ljubavi koje su Watts i Stenner (2005.) izdvojili Q-metodološkom studijom. Osim prikazane sukladnosti, uočavaju se i razlike. Sudionici Wattsova i Stennerova istraživanja opisuju dodatne osobine doživljaja ljubavi, kao što su: ljubav je odgovornost i rješavanje problema (pragmatičnu stranu partnerskog odnosa). Različito od navedenog, sudionici ovog istraživanja opisuju i altruističnu i duhovnu (nadnaravnu) komponentu ljubavi (v. Tablicu 2). Moguće je da je ova razlika uvjetovana razlikom u kulturom i demografijom oblikovanim osobinama sudionika; primjerice, u Wattsovu i Stennerovu istraživanju, koje obuhvaća relativno malen broj sudionika u uzorku (njih 50), sudjelovale su većinom osobe britanske nacionalnosti bez iskazanog religijskog uvjerenja, dok su se sudionici ovog istraživanja izjasnili kao umjereno religiozni, pa su kroz odabir studija zacijelo iskazali sklonost pomaganju drugima.

Je li zaljubljenost isto što i ljubav? Sudionici zaljubljenost ponekad smatraju integrativnim dijelom ljubavi, dok se kroz analizu izjava uočava njihova potreba da razdvoje ta dva osjećaja. Averill (1985., prema Oatley, Jenkins, 2003.) tvrdi da 
DRUŠ. ISTRAŽ. ZAGREB GOD. 21 (2012),

BR. 1 (115),

STR. 159-180

BARTOLAC, A.:

ZA MENE, LJUBAV JE...

\section{ZAKLJUČAK}

zaljubljivanje, kao i mnoge druge emocije, djeluje kao privremena socijalna uloga. Emocija biti zaljubljen omogućuje prijelaz iz jedne strukture socijalnih odnosa u drugu. Sudionici ovog istraživanja također su naglašavali tu razliku (Ljubav nije isto što i zaljubljenost; Zaljubljenost je osjećaj, ljubav - odnos). Suvremeno proturječje koje stvara najveći pritisak, a ujedno i pokazuje kulturalnu funkciju ove emocije, jest da zaljubljenost, kao razmjerno privremena emocija koja se javlja nakon kratkoga poznanstva, mora prijeći u doživotnu predanost (Oatley i Jenkins, 2003.; Watts i Stenner, 2005.). Oni smatraju da je $\mathrm{u}$ zapadnoj kulturi zaljubljivanje najdragocjenije osobno iskustvo, glorificirano u svim medijima. Ipak, sudionici ovog istraživanja jasno su razlučili ljubav od zaljubljenosti i čini se da im je ta razlika važna, odnosno da shvaćaju zaljubljenost kao intenzivan, ali prolazan osjećaj, a ljubav kao kompleksniji i trajniji odnos.

Zašto je ljubav toliko važna i zašto se toliko o njoj raspravlja, pitaju se Čudina-Obradović i Obradović (2006.) i zaključuju: vjerojatno zato što ljudi očekuju da će im ljubav donijeti najveće zadovoljstvo i sreću (a u sudionika ovog istraživanja dodatno i razumijevanje i poštovanje). Više od četrdeset godina nakon Knoxove prve konstrukcije i primjene ovog upitnika čini se da romantičnost kao kvaliteta ljubavi (barem u ovom uzorku) više nije prioritet. Važnije je razumijevanje i održavanje odnosa. Doživljaj ljubavi sudionika ovog istraživanja može se iskazati kategorijama: emocije, motivacija, socijalni odnosi i ponašanje. Sudionici ljubav doživljavaju kao kompleksnu emociju, motiviranu tjelesnim i duhovnim potrebama, koja u partnerskom smislu započinje zaljubljenošću, a zatim se razvija u odnos obilježen jednostranim ili uzajamnim ponašanjima davanja i primanja. Od ispitanih demografskih varijabli, samo su veličina mjesta odrastanja do punoljetnosti i stupanj religioznosti značajno povezani s izraženim stavom prema ljubavi, a pritom su značajno romantičniji oni sudionici koji su odrasli na selu te koji se izjašnjavaju kao izrazito religiozni.

Osnovno ograničenje ovog istraživanja očituje se u demografskim obilježjima analiziranoga prigodnog uzorka, koja onemogućuju generalizaciju rezultata na populaciju. Stoga je, uz već navedene, konačna preporuka za buduća istraživanja koja će se baviti ovom temom svakako proširiti ovaj nacrt na druge skupine sudionika, osobito s obzirom na rod (muški sudionici), (stariju) dob, razinu i vrstu obrazovanja, odnosno na veći i heterogeniji uzorak, koji bi dopunio sliku rezultata ovog istraživanja. 
Arnold, M. i Thompson, B. (1996.), Love Style Perceptions in Relation to Personality Function. Journal of Social Behavior E Personality, 11 (3): 425-438.

Aronson, E., Wilson, T. D. i Akert, R. M. (2005.), Socijalna psihologija, Zagreb, Mate.

Bailey, W., Hendrick, C. i Hendrick, S. (1987.), Relation of Sex and Gender Role to Love, Sexual Attitudes, and Self-Esteem. Sex Roles, 16 (11/12): 637-648. doi:10.1007/BF00300378

Cramer, D. (1993.), Dimensions of Romantic Love in British Female Adolescents. Journal of Social Psychology, 133 (3): 411-413. doi:10.1080/ 00224545.1993.9712163

Čudina-Obradović, M. i Obradović, J. (2006.), Psihologija braka i obitelji, Zagreb, Golden Marketing - Tehnička knjiga.

Dion, K. K. i Dion, K. L. (1993.a), Individualistic and Collectivistic Perspectives on Gender and the Cultural Context of Love and Intimacy. Journal of Social Issues, 49 (3): 53-69. doi:10.1111/j.1540-4560. 1993.tb01168.x

Dion, K. L. i Dion, K. K. (1993.b), Gender and Ethnocultural Comparisons in Styles of Love. Psychology of Women Quarterly, 17 (4): 463-473. doi:10.1111/j.1471-6402.1993.tb00656.x

Eysenck, M. (2008.), Fundamentals of Psychology, London, Psychology Press.

Fisher, H. E., Aron, A., Mashek, D., Li, H. i Brown, L. L. (2002.), Defining the Brain Systems of Lust, Romantic Attraction and Attachment. Archives of Sexual Behavior, 31 (5): 413-419. doi:10.1023/A:101 9888024255

Fowler, A. C. (2007.), Love and Marriage, Trough the Lens of Sociological Theories. Human Architecture: Journal of Sociological Self-Knowledge, 5 (2): 61-72.

Hatfield, E. i Sprecher, S. (1986.), Measuring Passionate Love in Intimate Relations. Journal of Adolescence, 9 (4): 383-410. doi:10.1016/S01401971(86)80043-4

Hendrick, C., Hendrick, S., Foote, F. H. i Slapion-Foote, M. J. (1984.), Do Men and Women Love Differently? Journal of Social and Personal Relationships, 1 (2): 177-195. doi:10.1177/0265407584012003

Hendrick, C., Hendrick, S. S. i Dicke, A. (1998.), The Love Attitudes Scale: Short Form. Journal of Social and Personal Relationships, 15 (2): 147-159. doi:10.1177/0265407598152001

Hendrick, C. i Hendrick, S. (1986.), A Theory and Method of Love. Journal of Personality E Social Psychology, 50 (2): 392-402. doi:10.1037// 0022-3514.50.2.392

Hendrick, S. S. i Hendrick, C. (2005.), Gender Differences and Similarities in Sex and Love. Personal Relationships, 2 (1): 55-65.

Hinkle, D. i Sporakowski, M. (1975.), Attitudes Toward Love: A Reexamination. Journal of Marriage and Family, 37 (4): 764-767. doi:10. $2307 / 350827$ 
DRUŠ. ISTRAŽ. ZAGREB GOD. 21 (2012), BR. 1 (115)

STR. 159-180

BARTOLAC, A.: ZA MENE, LJUBAV JE...
Knox, D. H. i Schacht, C. (2004.), Choices in Relationships: Introduction to Marriage and Family, Belmont, Wadsworth Publishing.

Knox, D. H. (1970.), Conceptions of Love at Three Developmental Levels. The Family Coordinator, 19 (2): 151-157. doi:10.2307/582445

Knox, D. H. i Sporakowski, M. J. (1968.), Attitudes of College Students Toward Love. Journal of Marriage and the Family, 30 (4): 638-642.

Lee, J. A. (1977.), A Typology of Styles of Loving. Personality and Social Psychology Bulletin, 3 (2): 173-182. doi:10.1177/014616727700300204

Levinger, G. (1994.), Figure versus Ground: Micro and Macro Perspectives on the Social Psychology of Personal Relationships. U: R. Erber i R. Gilmour (ur.), Theoretical Frameworks for Personal Relationships (str. 1-28), Erlbaum, Hillsdale, NJ.

Marazziti, D. (2005.), The Neurobiology of Love. Current Psychiatry Reviews, 1 (3): 331-335. doi:10.2174/157340005774575037

Masuda, M. (2003.), Meta-Analyses of Love Scales: Do Various Love Scales Measure the Same Psychological Constructs? Japanese Psychological Research, 45 (1): 25-37. doi:10.1111/1468-5884.00030

Medora, N., Larson, J., Hortaçsu, N. i Dave, P. (2002.), Perceived Attitudes Towards Romanticism; A Cross-Cultural Study of American, Asian-Indian, and Turkish Young Adults. Journal of Comparative Family Studies, 33 (2): 155-178.

Milivojević, Z. (2009.), Formule ljubavi, Zagreb, Mozaik knjiga.

Neto, F. (2007.), Love Styles: A Cross-Cultural Study of British, Indian, and Portuguese College Students. Journal of Comparative Family Studies, 38 (2), 239-254.

Oatley, K. i Jenkins, J. M. (2003.), Razumijevanje emocija, Jastrebarsko, Naklada Slap.

Reis, H. T. i Aron, A. (2008.), Love: What Is It, Why Does It Matter, and How Does It Operate? Perspectives on Psychological Science, 3 (1): 80-86. doi:10.1111/j.1745-6916.2008.00065.x

Rubin, Z. (1970.), Measurement of Romantic Love. Journal of Personality and Social Psychology, 16 (2): 265-273. doi:10.1037/h0029841

Shulman, S. i Scharf, M. (2000.), Adolescent Romantic Behaviors and Perceptions: Age- and Gender-Related Differences, and Links with Family and Peer Relationships. Journal of Research on Adolescence (Lawrence Erlbaum), 10 (1): 99-118. doi:10.1207/SJRA1001_5

Simmons, C. H., Vom Kolke, A. i Shmizu, H. (1986.), Attitudes toward Romantic Love Among American, German and Japanese Students. The Journal of Social Psychology, 126 (3): 327-336. doi:10.1080/00224545. 1986.9713593

Simmons, C. H., Wehner, E. A. i Kay, K. A. (1988.), Differences in Attitudes toward Romantic Love of French and American College Students. The Journal of Social Psychology, 129 (6): 793-799.

Sternberg, R. J. (1997.), Construct Validation of a Triangular Love Scale. European Journal of Social Psychology, 27 (3): 313-335. doi:10. 1002/(SICI)1099-0992(199705)27:3 <313::AID-EJSP824>3.0.CO;2-4;

Škokić, T. (2004.), Romantic Love. Narodna umjetnost, 41 (1): 145-165. 
DRUŠ. ISTRAŽ. ZAGREB GOD. 21 (2012)

BR. 1 (115),

STR. $159-180$

BARTOLAC, A.:

ZA MENE, LJUBAV JE..
Štulhofer, A. (2005.), Globalne spremembe: intimnost, momentalizem in spolnost. Emzin, 15 (1-2): 84-87.

Todosijević, B., Arančić, A. i Ljubiković, S. (2009.), An Examination and Revision of the Love Attitude Scale in Serbia. Interpersona, 3 (1): 55-74.

Watts, S. i Stenner, P. (2005.), The Subjective Experience of Partnership Love: A Q Methodological Study. British Journal of Social Psychology, 44 (1), 85-107. doi:10.1348/014466604X23473

To me, Love is...:

\section{Analysis of Student Attitudes and Experience of Romantic Love}

\begin{abstract}
Andreja BARTOLAC
University of Applied Health Studies, Zagreb

Love is certainly one of the most appealing aspects of emotional life and human behavior, which are rarely investigated in our environment, although there is a growing interest about this subject in the world (eg. Medora et al., 2002; Masuda, 2003; Watts \& Stenner, 2005; Hendrick \& Hendrick, 2005; Neto, 2007). Therefore, the research was conducted with the aim of learning how students of different ages experience love; what their attitudes toward romantic love are and whether some socio-demographic data are associated with attitudes toward the subject of measurement. The study involved 503 students who filled in Knox's Attitudes Toward Love Scale and in one sentence expressed their personal perception of love. This paper presents a quantitative and qualitative analysis of data pointing to a moderate expression of the romantic attitude of participants toward love. Through analysis of the examined demographic variables, it was shown that participants who grew up in a rural area and those who are very religious expressed a more romantic attitude toward love. Participants expressed their experience of love through the following categories: emotion, motivation, social relations and behavior. According to the statements of participants, it can be concluded that participants experience love as a complex emotion, motivated by physical and spiritual needs, which in the sense of partnership begins by infatuation and then develops into a relationship marked by unilateral or reciprocal behaviors of giving and receiving.
\end{abstract}

Keywords: romantic love, attitude, perception 